Distribution and Abundance of Gold and Other Selected Elements in Altered Bedrock, Empire Mining District, Clear Creek County, Colorado

GEOLOGICAL SURVEX BULLETIN $1278-\mathrm{C}$ 


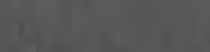

$a^{4}+10$

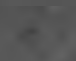




\section{Distribution and Abundance of Gold and Other Selected Elements in Altered Bedrock, Empire Mining District, Clear Creek County, Colorado}

By MAURICE A. CHAFFEE

CONTRIBUTIONS TO GEOGHEMICAL PROSPECTING FOR MINERALS

GE OLOGICA L SURVEY BULLETIN $1278-\mathrm{C}$

A study of the geological and geochemical relationships of gold anomalies to those of tellurium, tin, bismuth, silver, and manganese

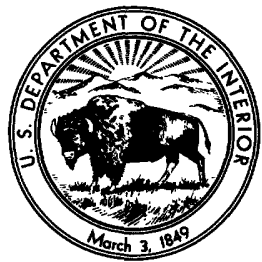




\section{UNITED STATES DEPARTMENT OF THE INTERIOR}

ROGERS C. B. MORTON, Secretary

\section{GEOLOGICAL SURVEY}

V. E. McKelvey, Director

Library of Congress catalog-card No. 72-600010

For sale by the Superintendent of Documents, U.S. Government Printing Office

Washington, D.C. 20402 - Price 30 cents

Stock Number 2401-2127 


\section{CONTENTS}

Abstract.

Introduction.

Acknowledgments

Geologic setting.

Alteration.

Sampling and analysis

Genesis of the elements under study.

Geochemical distribution maps

References cited.

\section{ILLUSTRATIONS}

Figure 1. Index maps showing locations of the Empire mining district and the upper and lower placers.

Page

C3

2. Photographs of the upper and lower placers

4-9. Maps of the lower placer showing distributions of metal anomalies and alteration intensities:

4. Gold

5. Tellurium.

6. Tin

7. Bismuth

8. Silver

9. Manganese

10. Geologic map of the upper placer

11-16. Maps of the upper placer showing distributions of metal anomalies and alteration intensities:

11. Gold

12. Tellurium

13. Tin

14. Bismuth

15. Silver

16. Manganese

\section{TABLES}

TABLE 1. Correlation coefficients of logarithms of concentrations of five selected elements relative to gold

2. Geochemical parameters for gold and five selected elements.

3. Analyses of sulfide concentrates, Tenth Legion mine... 



\author{
CONTRIBUTIONS TO GEOCHEMICAL PROSPECTING \\ FOR MINERALS
}

\title{
DISTRIBUTION AND ABUNDANCE OF GOLD AND OTHER SELECTED ELEMENTS IN ALTERED BEDROCK, EMPIRE MINING DISTRICT, CLEAR CREEK COUNTY, COLORADO
}

\author{
By Maurice A. Chaffee
}

\begin{abstract}
A geochemical study was made of altered bedrock samples from two placer areas in the Empire mining district, Colorado. Statistical study of the logarithms of the concentrations of 32 elements analyzed in these samples indicates that gold has linear correlation coefficients exceeding 0.55 with tellurium, tin, bismuth, and silver, and a linear correlation coefficient of -0.46 with manganese. Geochemical distribution maps show a degree of overlap of anomalies between these five selected elements and gold; this overlap exceeds 90 percent for each of the five elements. The areal distributions of all six of the elements studied seem to be related to the degree of alteration intensity that is observed in the field.

Analyses of surface bedrock samples suggest that the five selected elements are all pathfinder elements that would be useful in the search for gold mineralization in the Empire district. Data from unweathered underground samples from the district suggest that the amounts of tellurium, bismuth, silver, and manganese are closely related to the amount of hypogene gold. Tin values from the same samples, though mostly anomalous, do not show enough variation to establish any concentration trend relative to the trend of gold values. All six elements apparently behave chemically in a similar manner in the supergene environment of the area studied. In this district, tellurium would be the best pathfinder element to use in conjunction with gold for widespread reconnaissance exploration. The other four elements would be better suited for detailed studies.
\end{abstract}

\section{INTRODUCTION}

A comprehensive geochemical investigation of the distribution of selected trace elements in various media was undertaken by the U.S. Geological Survey in 1967 in the northern part of the Empire mining district, Clear Creek County, Colorado, about 37 miles west of Denver in the Front Range of the Rocky Mountains (fig. 1). Previous reports of that investigation (Curtin and others, 1968, 
1971) discussed the distribution and abundance of trace metals in humus-rich forest soil (mull) in the district. This report discusses the distribution and abundance of a selected suite of trace metals in bedrock in two gold-placer areas in the district (fig. 1).

Much of the Empire district is covered with colluvial or glacial deposits. The two placer areas were selected for this geochemical study because they have a greater than usual amount of exposed bedrock for this region (fig. 2) and are near known mineralized structures.

\section{ACKNOWLEDGMENTS}

I was assisted in the field by G. C. Curtin, H. W. Lakin, and H. D. King. Chemical analyses were made by. E. L. Mosier, K. C. Watts, A. E. Hubert, W. W. Janes, R. L. Turner, J. R. Watterson, and J. G. Frisken. I thank Messrs. H. C. Nelson and E. J. Woodriff for granting permission to publish data on samples collected on their properties.

\section{GEOLOGIC SETTING}

The geology of the Empire district has been most recently described by Braddock (1969). Formations include Precambrian igneous and metamorphic rocks that have been intruded by felsic to intermediate igneous rocks of Tertiary age. Quaternary glacial deposits, alluvium, talus, and solifluction debris cover about onethird of the pre-Quaternary rocks in the Empire quadrangle (Braddock, 1969, p. 45).

Within the two areas studied, exposures of Boulder Creek Granite and biotite gneiss, both of Precambrian age (Braddock, 1969), predominate (figs. 3, 10). Except for some minor exposures of bostonite porphyry in the upper placer (fig. 10), no Tertiary units crop out in either placer.

For this study, four post-Tertiary units have been mapped. These are glacial moraine and talus (both Quaternary), placer tailings, and mine tailings. Glacial moraine is found around the perimeter of the two areas studied; there, no placer mining has been done, and the original surface remains virtually undisturbed. Parts of the two placers (especially their perimeters) have, as a result of the placering, steep slopes on which eroded material derived from glacial moraine or weathered bedrock, or both, has locally moved downward from the rim of the placer and has partly covered the underlying bedrock. Such areas have been mapped as talus but actually comprise a mixture of transported and residual materials and many small outcrops of bedrock. Areas of both placers mapped as placer tailings are covered by piles of glacial boulders remaining 


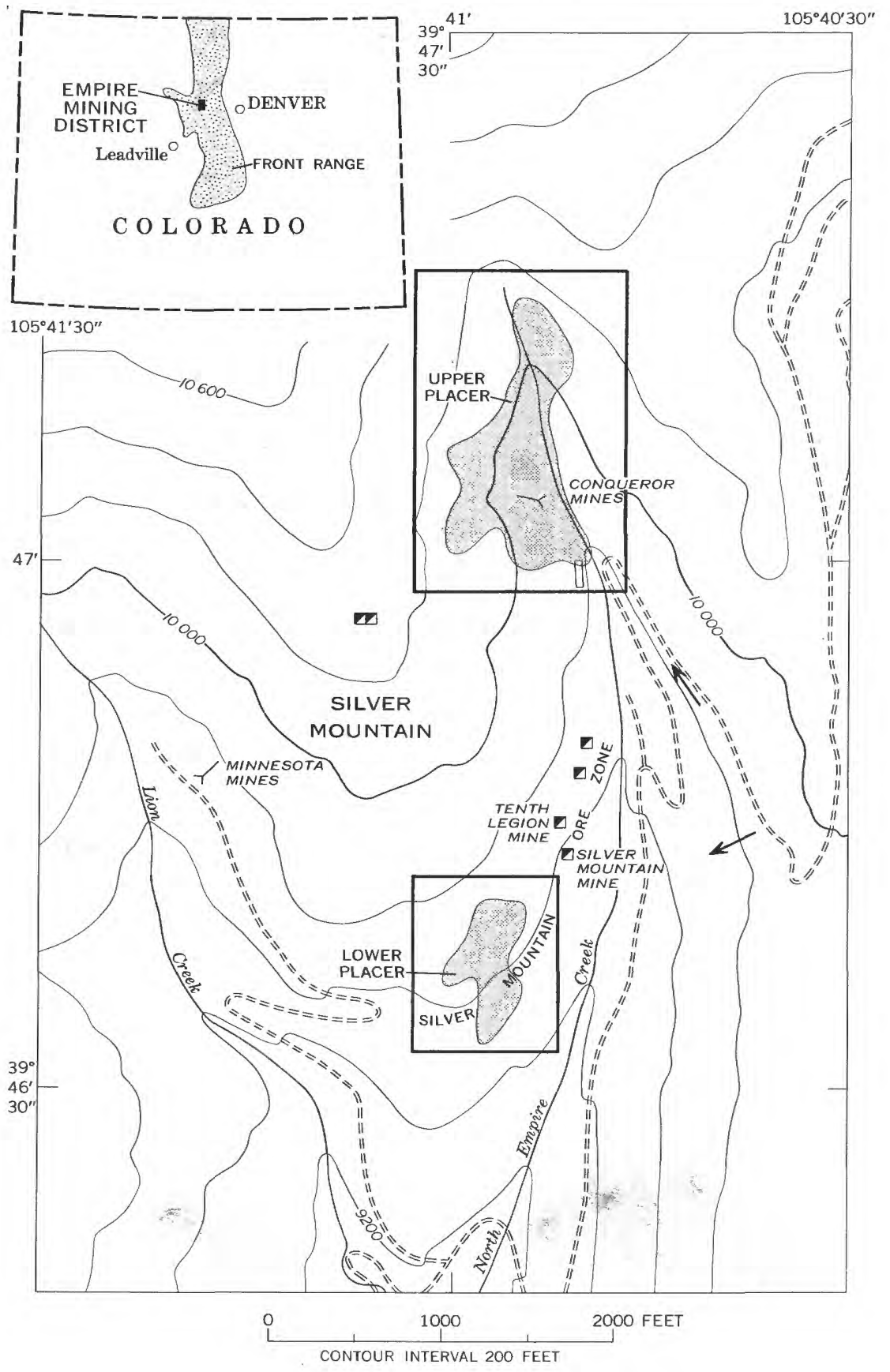

Figure 1.-Index maps showing location of the Empire mining district and the upper and lower placers. Arrows indicate direction of views shown in figure 2. Rectangles indicate areas shown in figures $3-16$. 
after placer operations. Areas mapped as mine tailings consist mostly of material originally mined underground. This material
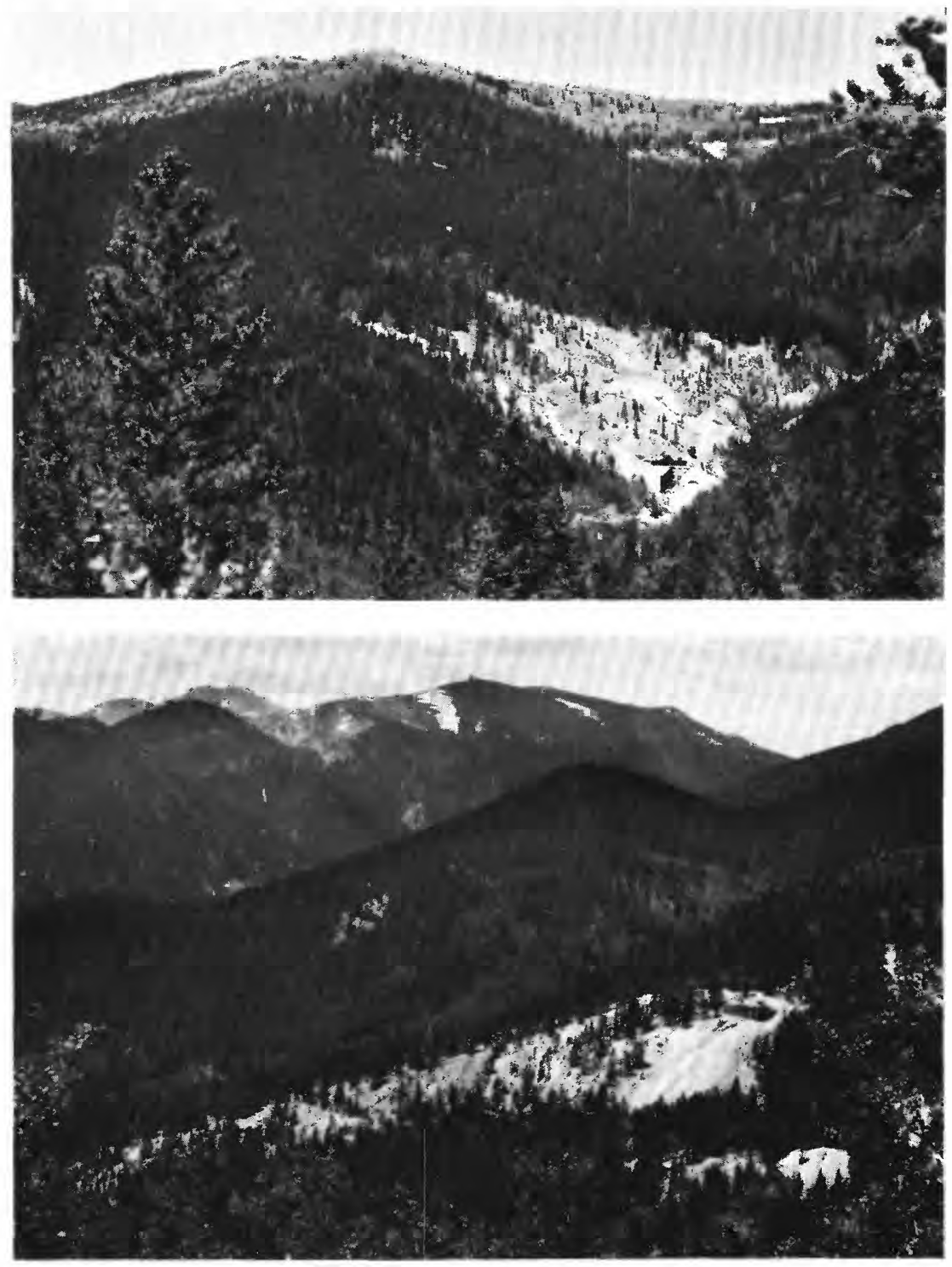

Figure 2.-Upper placer (above) and lower placer (below). These two areas, still lacking vegetation, were originally covered with natural growth and as much as 40 feet of residual oxidized and decomposed bedrock. As a consequence of hydraulic placer mining of this altered bedrock in the 1860's, during which the original soil was removed, natural reforestation has been greatly inhibited. Orientation of these photographs is shown in figure 1. 
now consists of weathered sulfides and strongly argillized host rocks of the various formations found in the district.

\section{ALTERATION}

Bedrock in both placers has been subjected to varying degrees of both hydrothermal alteration and weathering; however, most of the observed alteration is probably hydrothermal. Where alteration caused by weathering has been superimposed on hydrothermally sulfidized areas, alteration has been accelerated because the oxidation of sulfides has produced highly acid ground conditions.

A rough estimate of the intensity of alteration was made at each bedrock sample site. Completely unaltered bedrock was not seen in either placer. The bedrock was considered weakly altered if the dark mafic minerals present in either of the two dominant rock types appeared substantially unaltered in a hand specimen. It was considered moderately altered if it contained argillized feldspars and bleached mafic minerals and strongly altered if it contained visible sericite and (or) aphanitic silica in addition to the argillized feldspars and the bleached mafic minerals. Alteration intensity zones based on these alteration features are shown on all maps in figures 4-9 and 11-16.

The lower placer contains extensive exposures of weakly to strongly altered biotite gneiss and minor exposures of weakly altered Boulder Creek Granite. Alteration intensity seems to be crudely zoned around a center near the middle of the placer. (See, for example, fig. 4.) Sericite and aphanitic silica are visible on fracture surfaces in this central area. The conduit for the hydrothermal fluids associated with this alteration zoning was probably one or more of the shear zones forming the Silver Mountain ore zone (fig. 1).

Bedrock in the upper placer (fig. 11, for example) is not as intensely altered as it is in the lower placer; sericite was nowhere observed, and aphanitic silica is not as widespread. In a crude manner, the alteration intensity here also increases gradually toward the center of the placer. These intensity zones do not seem to be closely related to faults, geologic contacts, or lithology.

\section{SAMPLING AND ANALYSIS}

Bedrock samples were collected on an approximately 50-foot grid wherever bedrock was available at or near the surface. Care was exercised to avoid sampling too near to mine and placer tailings and to other obvious sources of sample contamination. Sample sites in talus areas are isolated outcrops, most of which are too small to show on the geologic maps. Sample sites in the areas of morainal deposits are prospect pits that penetrated to bedrock. Sampling 
was done at depths ranging from about 0 to 6 inches. The sampled bedrock material varied from soft, deeply altered saprolite to dense, highly resistant, silicified rock. All samples were ground to pass through a 150 -micron sieve opening before analysis.

Several techniques were used to obtain the reported analyses. Gold was determined by atomic absorption (Thompson and others, 1968), tellurium by a wet chemical method (Lakin and Thompson, 1963), mercury by atomic absorption (Vaughn and McCarthy, 1964), and the other elements by a semiquantitative spectrographic method (Grimes and Marranzino, 1968). Most of the analyses were made in the field.

All samples were analyzed for 32 elements, and all values within the limits of determination from these analytical data were used as computer input. Output included basic descriptive statistics, frequency distributions, and linear product-moment correlation coefficients between pairs of logarithms of all 32 elements. Table 1

TABLE 1.-Correlation coefficients of logarithms of concentrations of five selected elements relative to gold

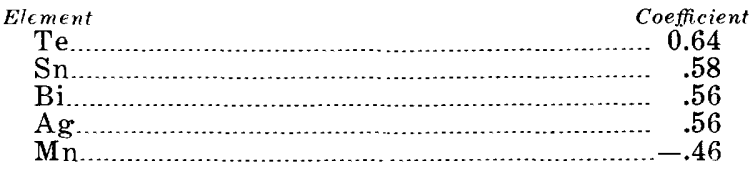

lists the five elements that had correlation coefficients greater than an absolute value of 0.45 when compared with gold. Because 26 of the analyzed elements had correlation coefficients less than an absolute value of 0.45 relative to gold, ${ }^{1}$ the relationship of these elements to gold was arbitrarily considered not significant in terms of prospecting value, and these elements were not studied further. The concentration ranges, background values, and threshold values for the five selected elements and gold are given in table 2.

Background and threshold values were primarily determined from a study of cumulative frequency distributions constructed on log-probability paper. Plots were made and interpreted in a manner similar to that described by Lepeltier (1969). Where determination of the background and threshold values of a given element was not clear from this plot, arbitrary values were assigned after additionally considering observed field relationships and areal distribution patterns of analyses of the given element. For five of the six elements, the background value is below the sensitivity of the analytical method used.

${ }^{1}$ These 26 elements are $\mathrm{Fe}, \mathrm{Mg}, \mathrm{Ca}, \mathrm{Ti}, \mathrm{As}, \mathrm{Sb}, \mathrm{B}, \mathrm{Ba}, \mathrm{Be}, \mathrm{Cd}, \mathrm{Co}, \mathrm{Cr}, \mathrm{Cu}, \mathrm{Hg}$, La, Mo, Nb, $\mathrm{Ni}, \mathrm{Pb}, \mathrm{Sc}, \mathrm{Sr}, \mathrm{V}, \mathrm{W}, \mathrm{Y}, \mathrm{Zn}$, and $\mathrm{Zr}$. 
TABLE 2.-Geochemical parameters (in parts per million) for gold and five selected elements

\begin{tabular}{|c|c|c|c|}
\hline Element & $\begin{array}{l}\text { Concentration } \\
\text { range }\end{array}$ & $\begin{array}{l}\text { Background } \\
\text { value }\end{array}$ & $\begin{array}{c}\text { Threshold } \\
\text { value }\end{array}$ \\
\hline $\mathrm{Au}$ & $<0.04-$ & (1) & 0.06 \\
\hline Те & $<.1-85$ & (1) & .3 \\
\hline Sn & -150 & $(1)$ & 10 \\
\hline (2) & -200 & (1) & 10 \\
\hline $\mathrm{Ag}$.. & $<.5-70$ & (1) & .7 \\
\hline Mn.. & $-5,000$ & 200 & 70 \\
\hline
\end{tabular}

${ }^{1}$ Below the limit of analytical detection. The limits are: $\mathrm{Au}, 0.04 \mathrm{ppm}$ (parts per million); $\mathrm{Te}, 0.1 \mathrm{ppm} ; \mathrm{Sn}, 10 \mathrm{ppm} ; \mathrm{Bi}, 10 \mathrm{ppm}$; and $\mathrm{Ag}, 0.5 \mathrm{ppm}$.

\section{GENESIS OF THE ELEMENTS UNDER STUDY}

To determine whether the gold and the five selected pathfinder elements had a common hypogene ancestry, four virtually unweathered sulfide samples were collected between 30 and 200 feet below the surface in the Tenth Legion mine, just north of the lower placer (fig. 1). Analyses of sulfide concentrates from these samples show, relative to their respective contents in the country rock (table 2 background values), a common enrichment of gold, silver, bismuth, tellurium, and, perhaps, tin and a corresponding depletion of manganese (table 3 ). These results suggest that the

TABLE 3.-Analyses (in parts per million) of sulfide concentrates, Tenth Legion mine

\begin{tabular}{|c|c|c|c|c|c|c|c|}
\hline $\begin{array}{c}\text { Sample } \\
\text { No. }\end{array}$ & $\mathrm{Au} \mathrm{u}^{1}$ & $\mathrm{Te}^{2}$ & $\mathrm{Sn}^{3}$ & $\mathrm{Bi}^{3}$ & $\operatorname{Ag}^{3}$ & $\mathrm{Mn}^{3}$ & $\begin{array}{c}\text { Sample } \\
\text { description }\end{array}$ \\
\hline $\mathrm{U}-7, \ldots$ & $\ldots . .230$ & 21 & 20 & $>1,000$ & 200 & 10 & $\begin{array}{l}\text { Pyrite and minor } \\
\text { amounts of } \\
\text { chalcopyrite. }\end{array}$ \\
\hline $\begin{array}{lll}11 & \ldots\end{array}$ & .. 160 & 12 & 30 & 1,000 & 30 & 15 & Do. \\
\hline $73 \quad \ldots$ & 90 & 14 & (4) & 150 & 30 & 30 & Do. \\
\hline $62 \ldots \ldots$ & .. 60 & 11 & 30 & 50 & 2 & 150 & $\begin{array}{c}\text { Virtually all } \\
\text { pyrite. }\end{array}$ \\
\hline
\end{tabular}

'Atomic absorption analysis by A. E. Hubert.

"Atomic absorption analysis by R. L. Turner.

Spectrographic analysis by E. L. Mosier.

${ }^{4} \mathrm{~B}+\mathrm{l}$ ow the limit of analytical detection $(10 \mathrm{ppm})$.

initial concentrations of at least five (excluding tin) of these particular elements are related to the hypogene gold mineralization. Tin values do not show enough variation to establish any concentration trend relative to the trend of gold values. The high correlation coefficient values and coincident areal distributions for gold and the five selected elements as determined from the surfacesample data further suggest that these six elements behave chemically in a similar manner in the supergene environment of the area studied. 


\section{GEOCHEMICAL DISTRIBUTION MAPS}

Geochemical maps (figs. 4-9, 11-16) show that (1) the distributions of anomalies of gold and the five selected elements have a high degree of overlap (90-100 percent) ; $(2)$ both positive and negative anomalies in the lower placer are generally associated with bedrock which has been at least moderately altered; this association is similar but not as pronounced in the upper placer; (3) the distributions of gold and the five selected elements have no obvious correlation with rock type; and (4) tellurium has a broader anomaly pattern than the other pathfinder elements.

Because of the wider distribution of its anomalies, tellurium seems to be the best pathfinder element to use in conjunction with gold for widespread reconnaissance work. The more restricted distributions of tin, bismuth, silver, and manganese anomalies seem best suited for more detailed studies. The use of negative anomaly maps, such as those of maganese in this study, should be considered in other geochemical studies.

\section{REFERENCES CITED}

Braddock, W. A., 1969, Geology of the Empire quadrangle, Grand, Gilpin, and Clear Creek Counties, Colorado: U.S. Geol. Survey Prof. Paper 616, $56 \mathrm{p}$.

Curtin, G. C., Lakin, H. W., Neuerburg, G. J., and Hubert, A. E., 1968, Utilization of humus-rich forest soil (mull) in geochemical exploration for gold: U.S. Geol. Survey Circ. 562, 11 p.

Curtin, G. C., Lakin, H. W., Hubert, A. E., Mosier, E. L., and Watts, K. C., 1971, Utilization of mull (forest humus layer) in geochemical exploration in the Empire district, Clear Creek County, Colorado: U.S. Geol. Survey Bull. 1278-B, 39 p.

Grimes, D. J., and Marranzino, A. P., 1968, Direct-current arc and alternatingcurrent spark emission spectrographic field methods for the semiquantitative analysis of geologic materials: U.S. Geol. Survey Circ. 591, 6 p.

Lakin, H. W., and Thompson, C. E., 1963, Tellurium-A new sensitive test: Science, v. 141 , no. 3575 , p. $42-43$.

Lepeltier, Claude, 1969, A simplified statistical treatment of geochemical data by graphical representation: Econ. Geology, v. 64, no. 5, p. 538-550.

Thompson, C. E., Nakagawa, H. M., and VanSickle, G. H., 1968, Rapid analysis for gold in geologic materials, in Geological Survey research 1968: U.S. Geol. Survey Prof. Paper 600-B, p. B130-B132.

Vaughn, W. W., and McCarthy, J. H., Jr., 1964, An instrumental technique for the determination of submicrogram concentrations of mercury in soils, rocks, and gas, in Geological Survey research 1964: U.S. Geol. Survey Prof. Paper 501-D, p. D123-D127. 


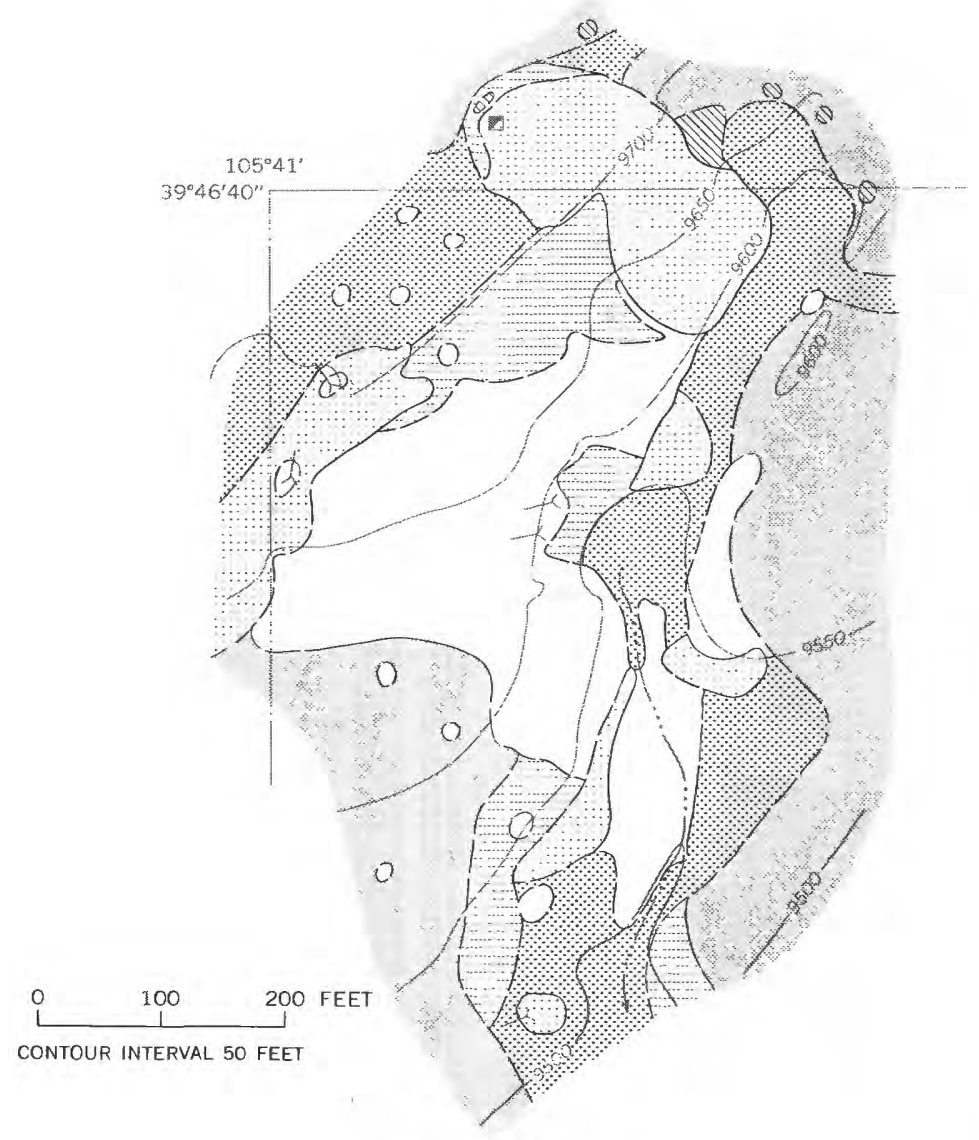

EXPLANATION

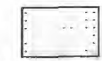

Mine tailings

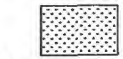

Placer tailings

Predominantly glacial boulders remaining after placer mining

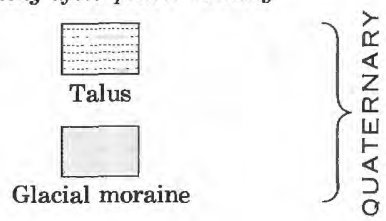

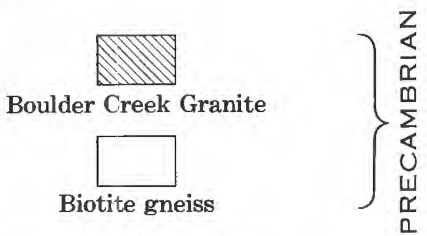

Contact

Dashed where approximately located

Adit

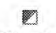

Shaft

Figure 3.-Geologic map of the lower placer. 


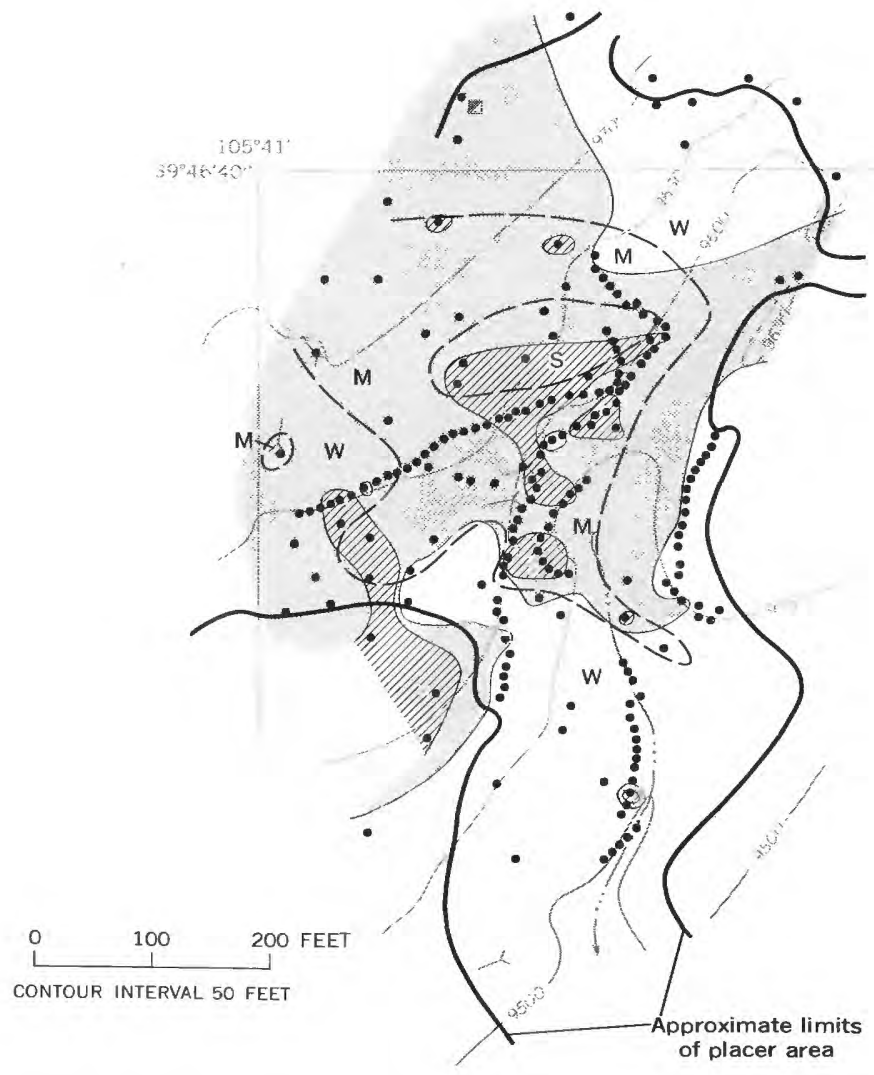

EXPLANATION
Approximate boundary between areas of different alteration intensity
W, Weakly altered bedrock
M, Moderately altered bedrock
$\mathrm{S}$, Strongly altered bedrock

$$
\text { Sample site }
$$

FIgURE 4.-Distribution of gold anomalies and alteration intensities in bedrock, lower placer. 


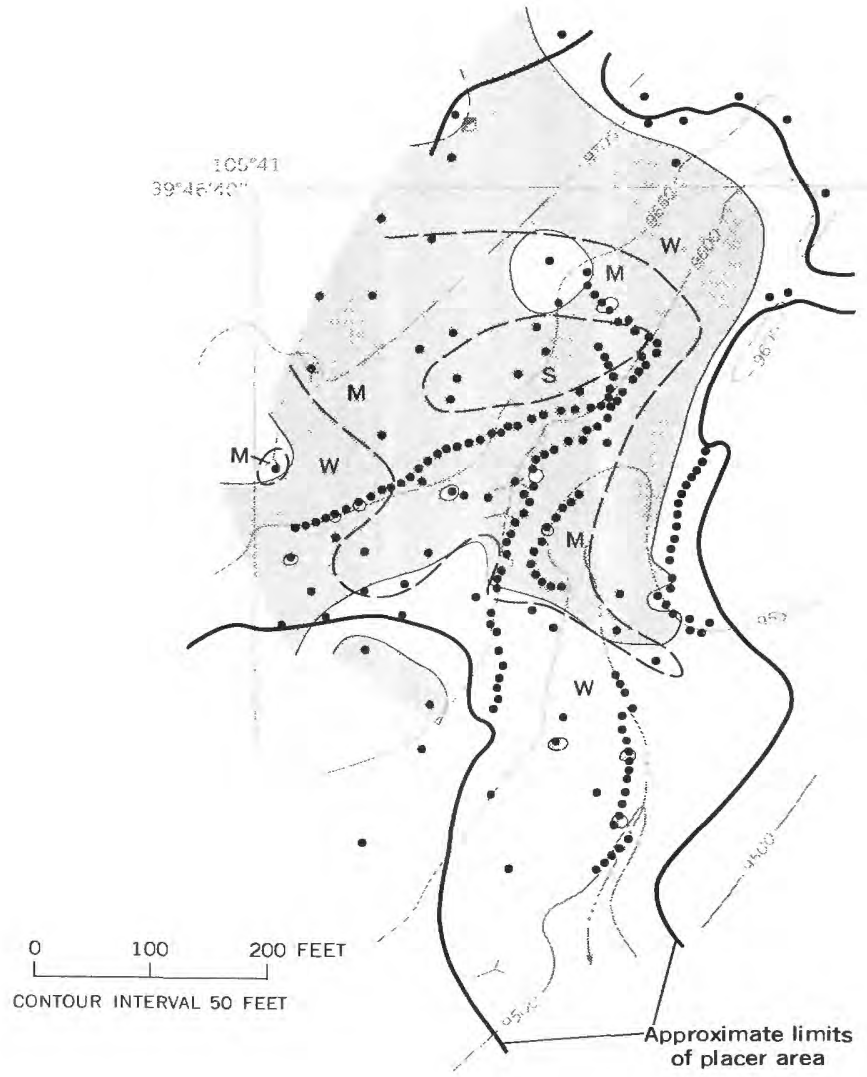

\section{EXPLANATION}

Approximate boundary between areas of different alteration intensity

W, Weakly altered bedrock

$\mathrm{M}$, Moderately altered bedrock

$\mathrm{S}$, Strongly altered bedrock

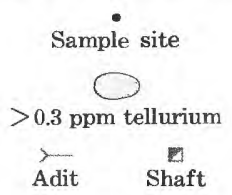

FIGURE 5.-Distribution of tellurium anomalies and alteration intensities in bedrock, lower placer. 


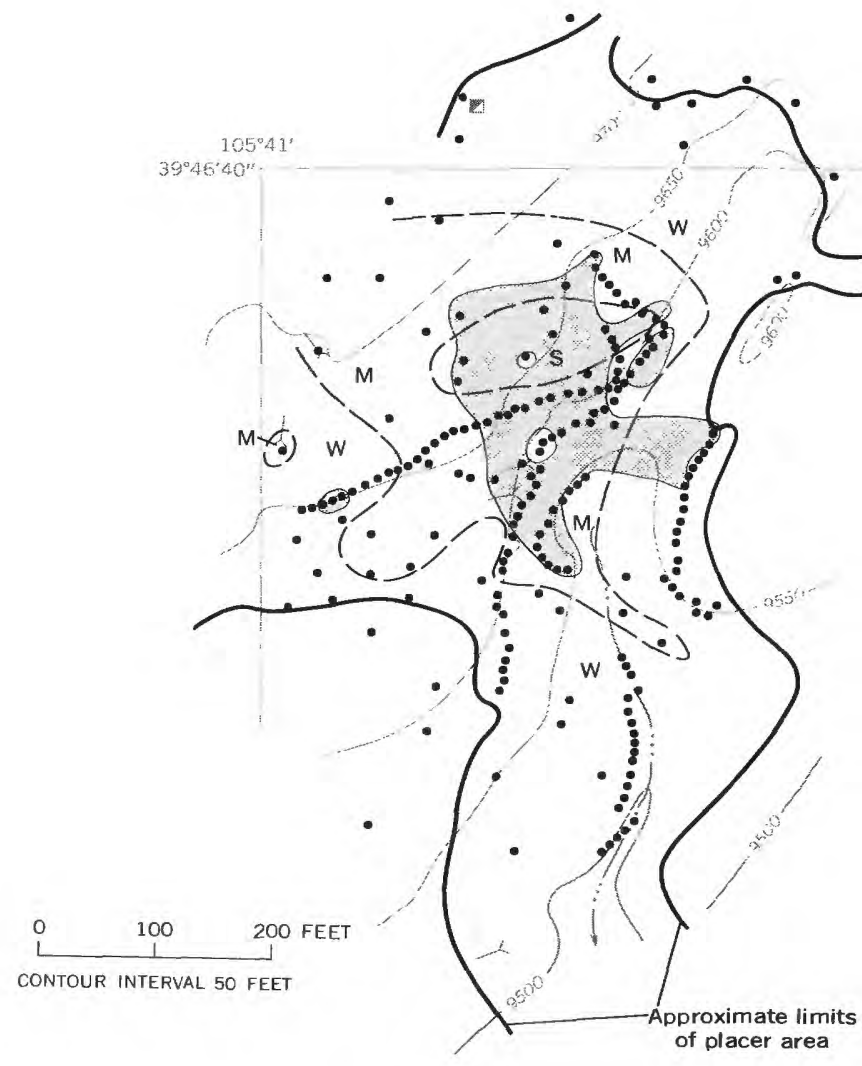

EXPLANATION
Approximate boundary between areas of different alteration intensity
W, Weakly altered bedrock
$\mathrm{M}$, Moderately altered bedrock
S, Strongly altered bedrock

$$
\text { Sample site }
$$

Figure 6.-Distribution of tin anomalies and alteration intensities in bedrock, lower placer. 


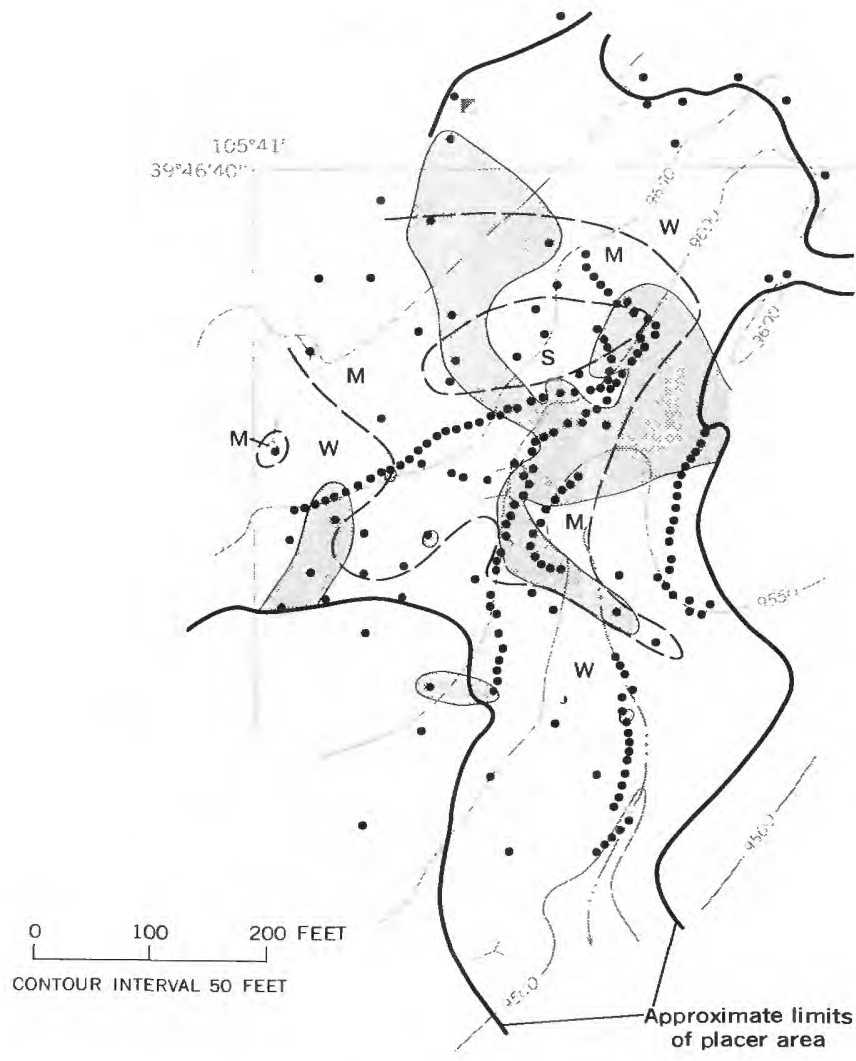

EXPLANATION

Approximate boundary between areas of different alteration intensity

W, Weakly altered bedrock

$\mathrm{M}$, Moderately altered bedrock

$\mathrm{S}$, Strongly altered bedrock

Sample site

$>10$ ppm bismuth

FIGURE 7.-Distribution of bismuth anomalies and alteration intensities in bedrock, lower placer. 


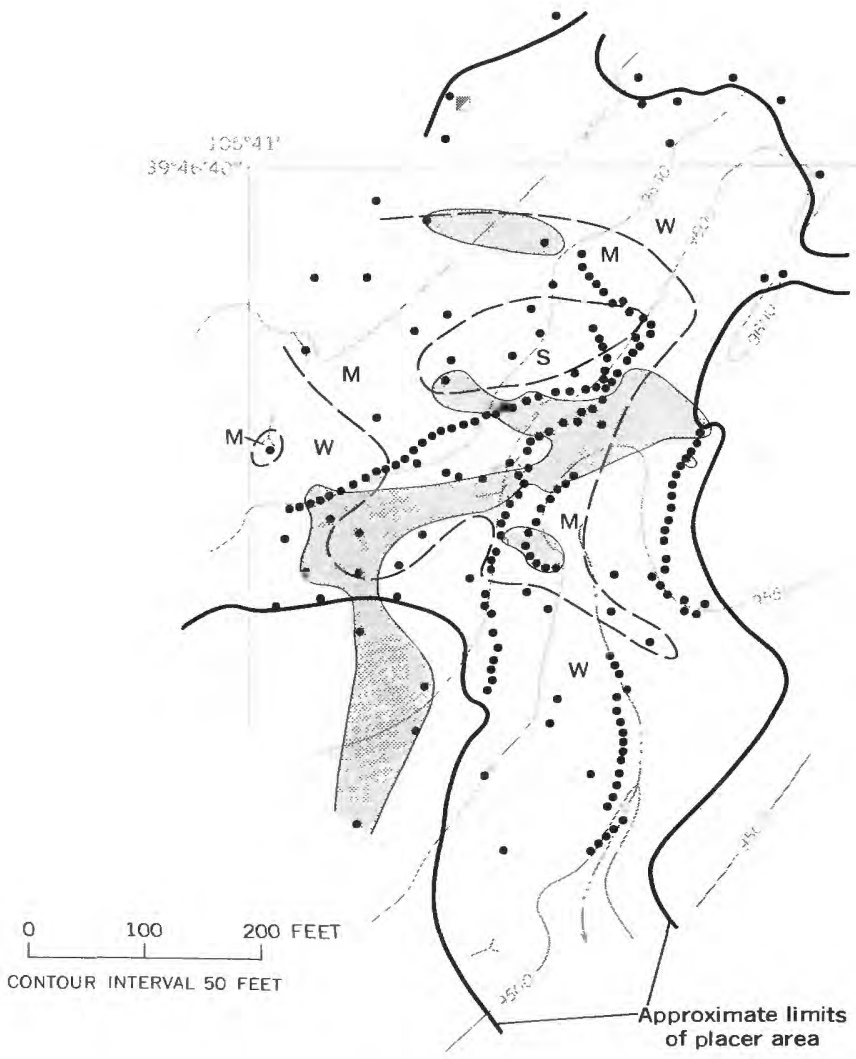

EXPLANATION
Approximate boundary between areas of different alteration intensity
W, Weakly altered bedrock
$\mathrm{M}$, Moderately altered bedrock
$\mathrm{S}$, Strongly altered bedrock

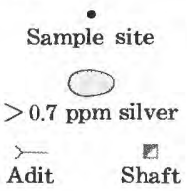

FIGURE 8.-Distribution of silver anomalies and alteration intensities in bedrock, lower placer. 


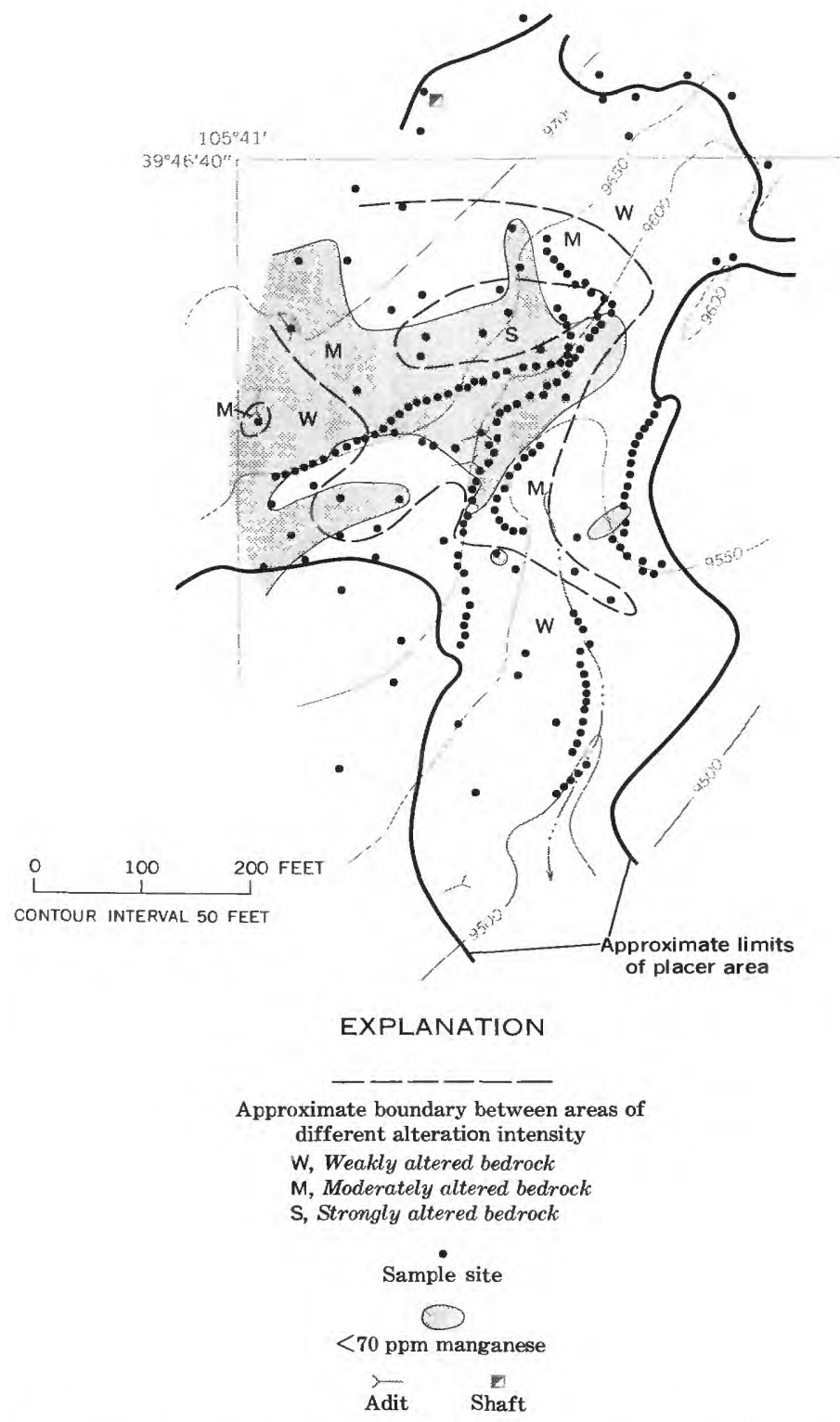

FIGURE 9.-Distribution of manganese anomalies and alteration intensities in bedrock, lower placer. 


\section{C16 CONTRIBUTIONS TO GEOCHEMICAL PROSPECTING FOR MINERALS}

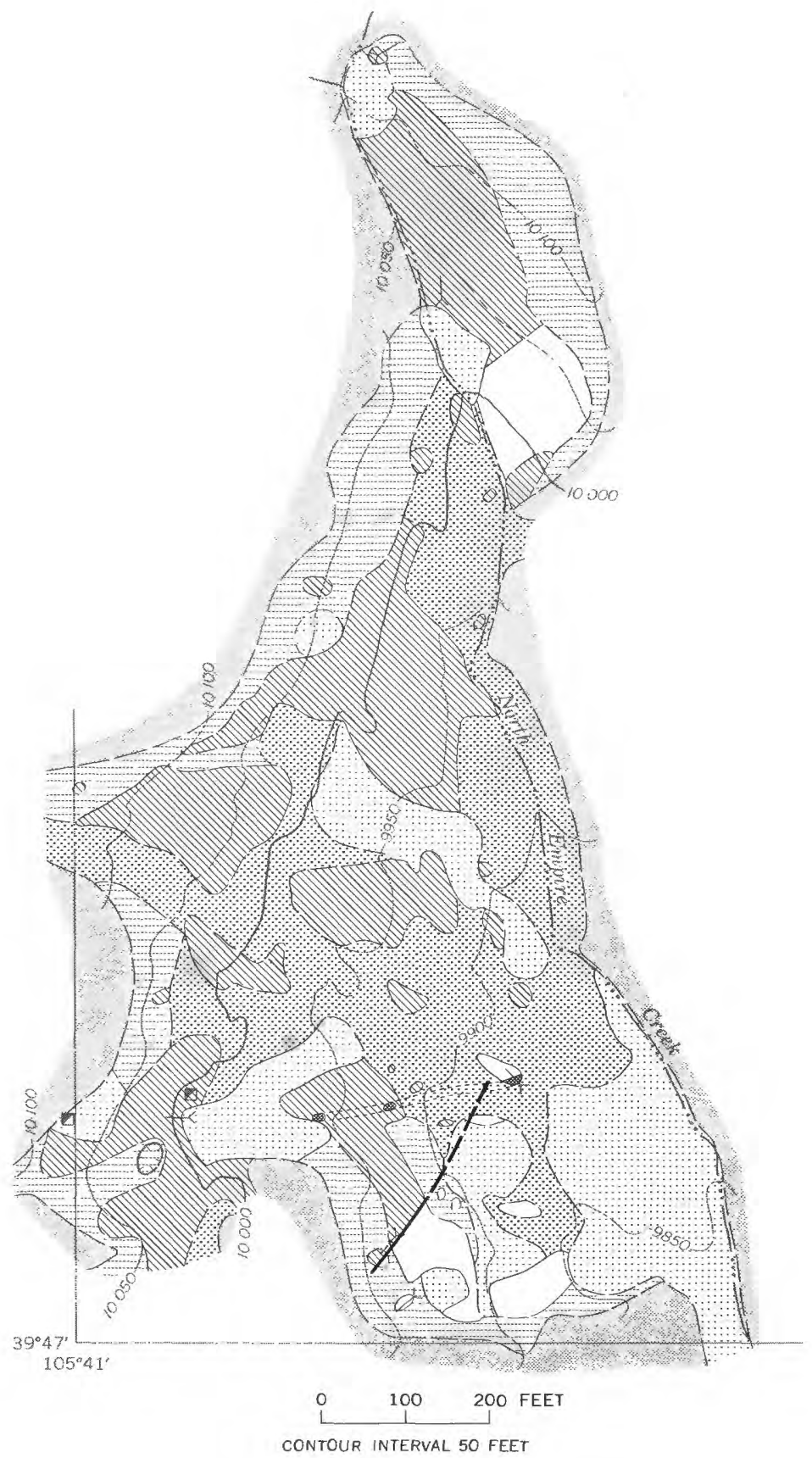

Figure 10.-Geologic map of the upper placer. 
GOLD AND OTHER ELEMENTS, EMPIRE MINING DISTRICT, COLO. C17

\section{EXPLANATION}

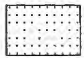

Mine tailings

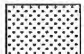

Placer tailings

Predominantly glacial boulders remaining after placer mining

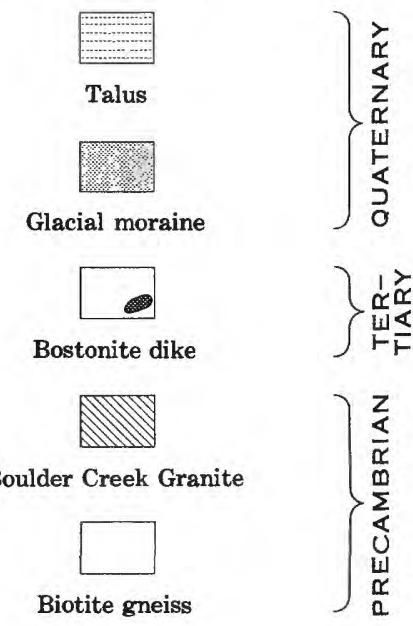

\section{Contact}

Dashed where approximately located; dotted where inferred

Fault

Dashed where approximately located

$\succ$

Adit

ธ

Shaft 


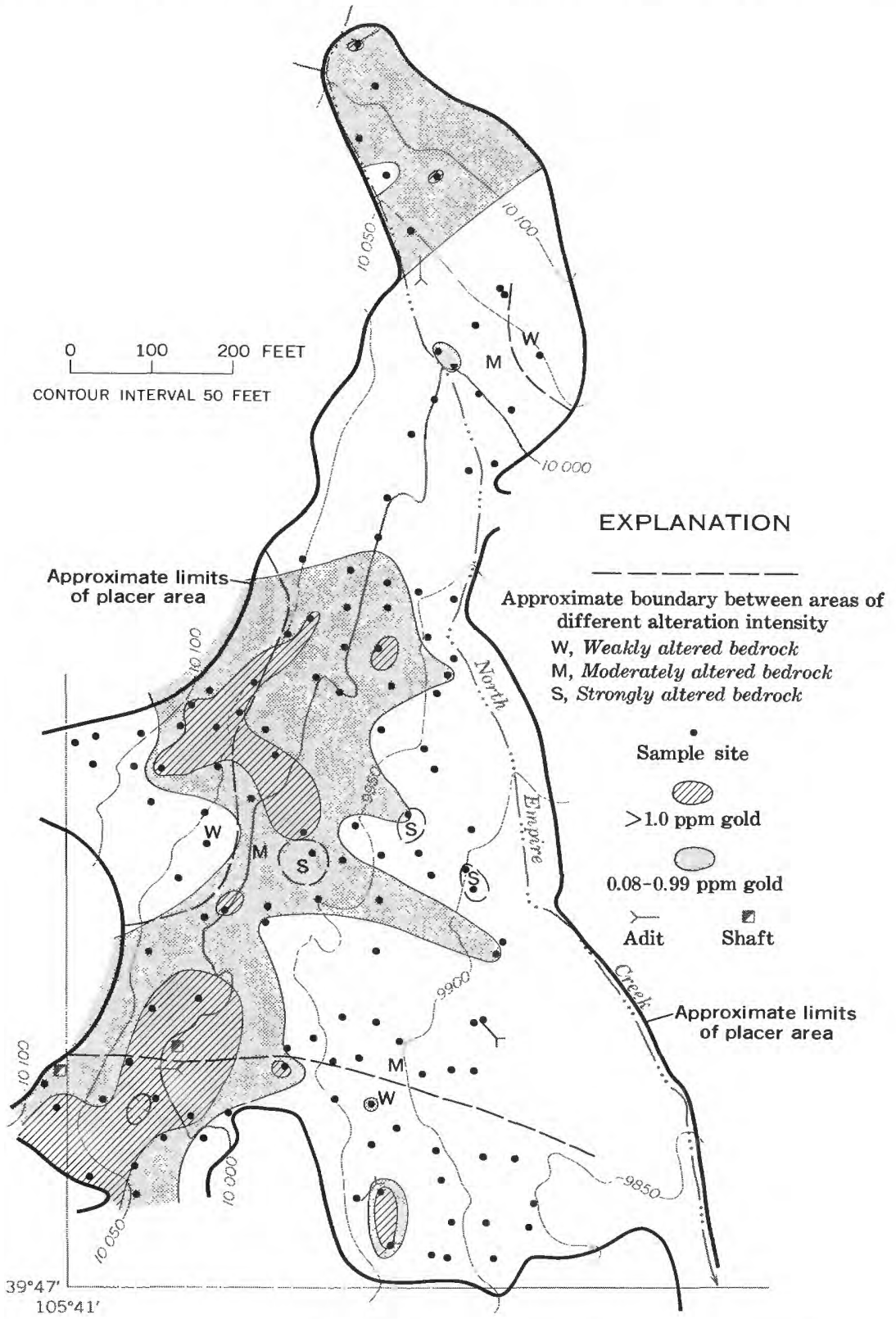

Figure 11.-Distribution of gold anomalies and alteration intensities in bedrock, upper placer. 


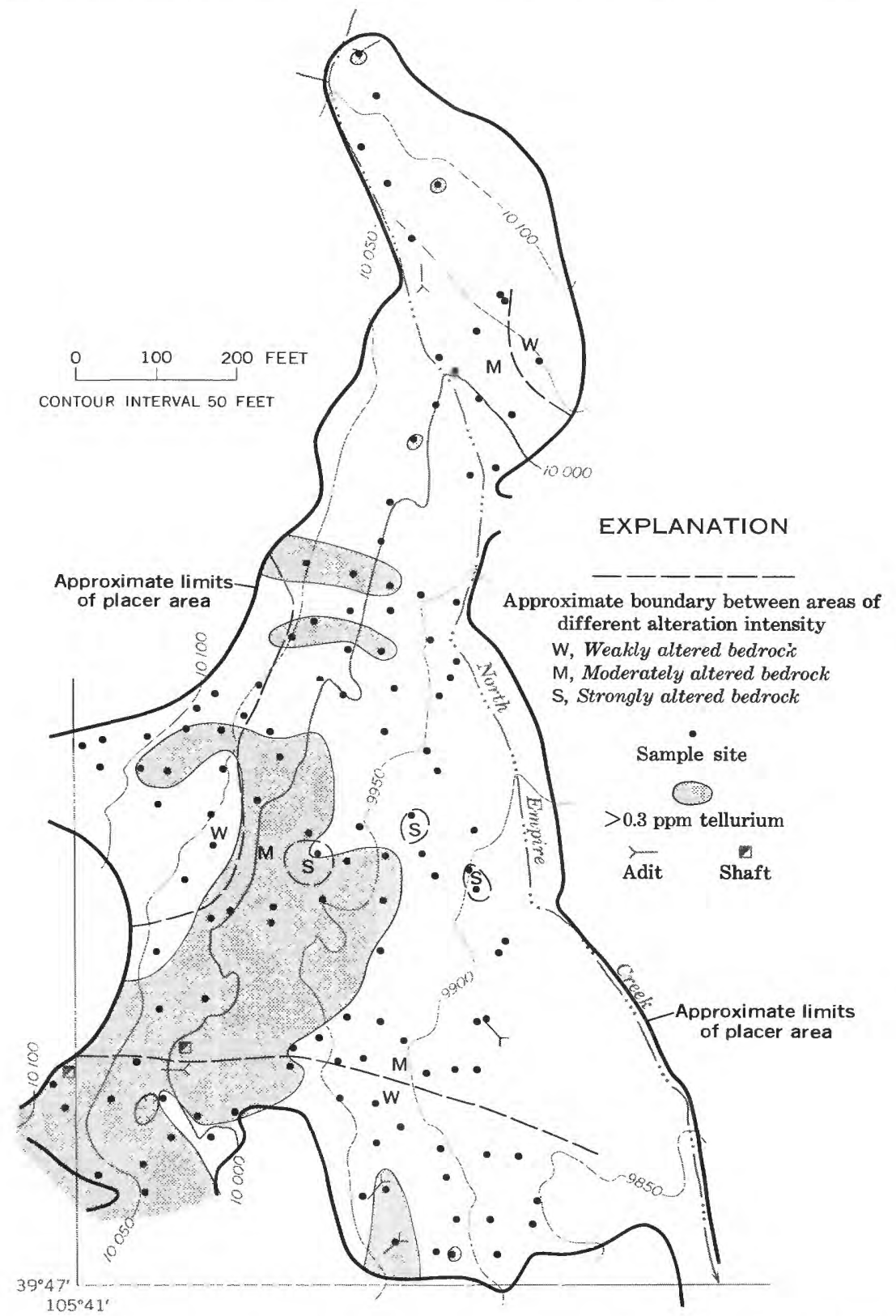

FigURE 12,-Distribution of tellurium anomalies and alteration intensities in bedrock, upper placer. 


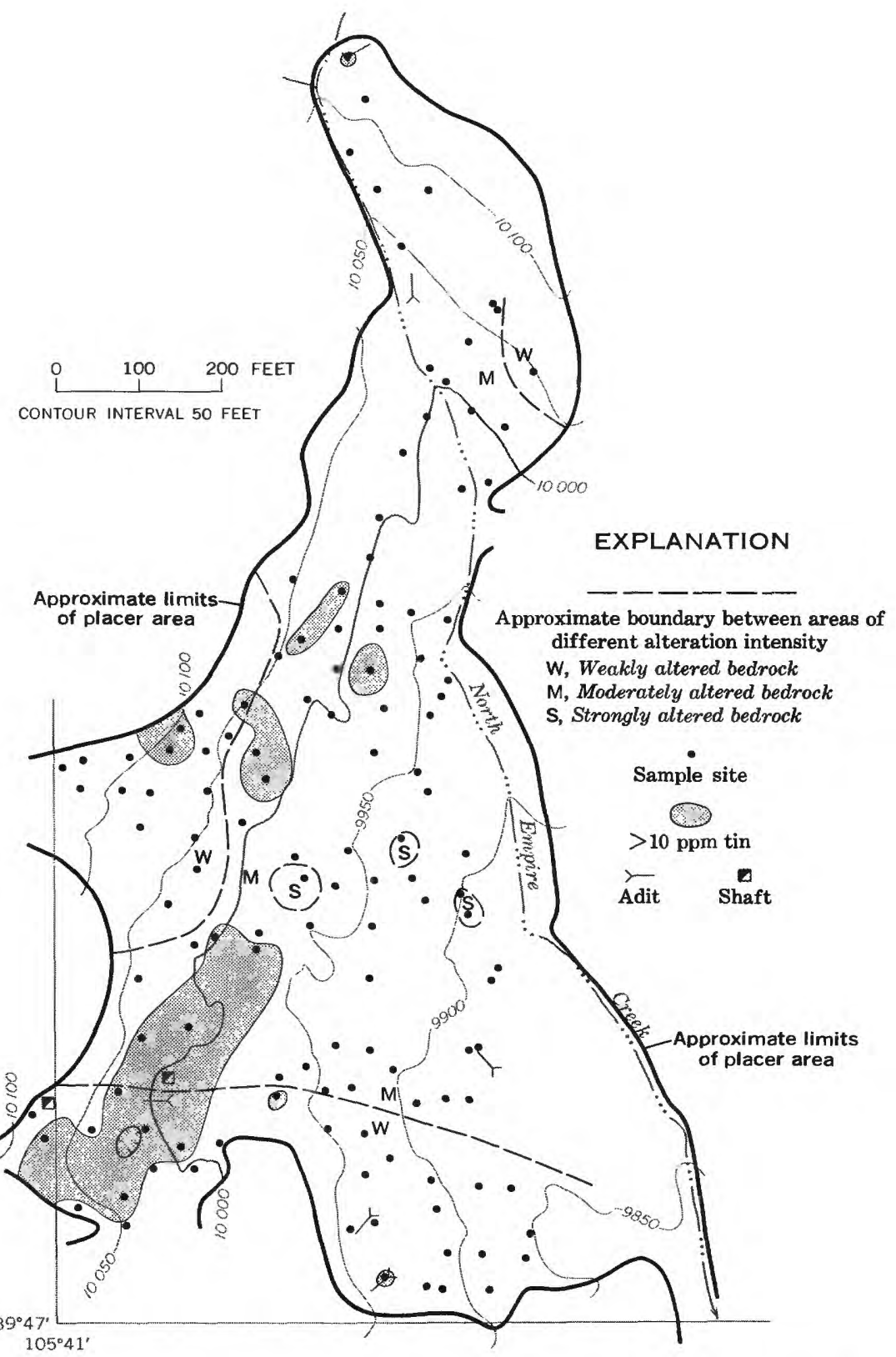

FIGURE 13.-Distribution of tin anomalies and alteration intensities in bedrock, upper placer. 


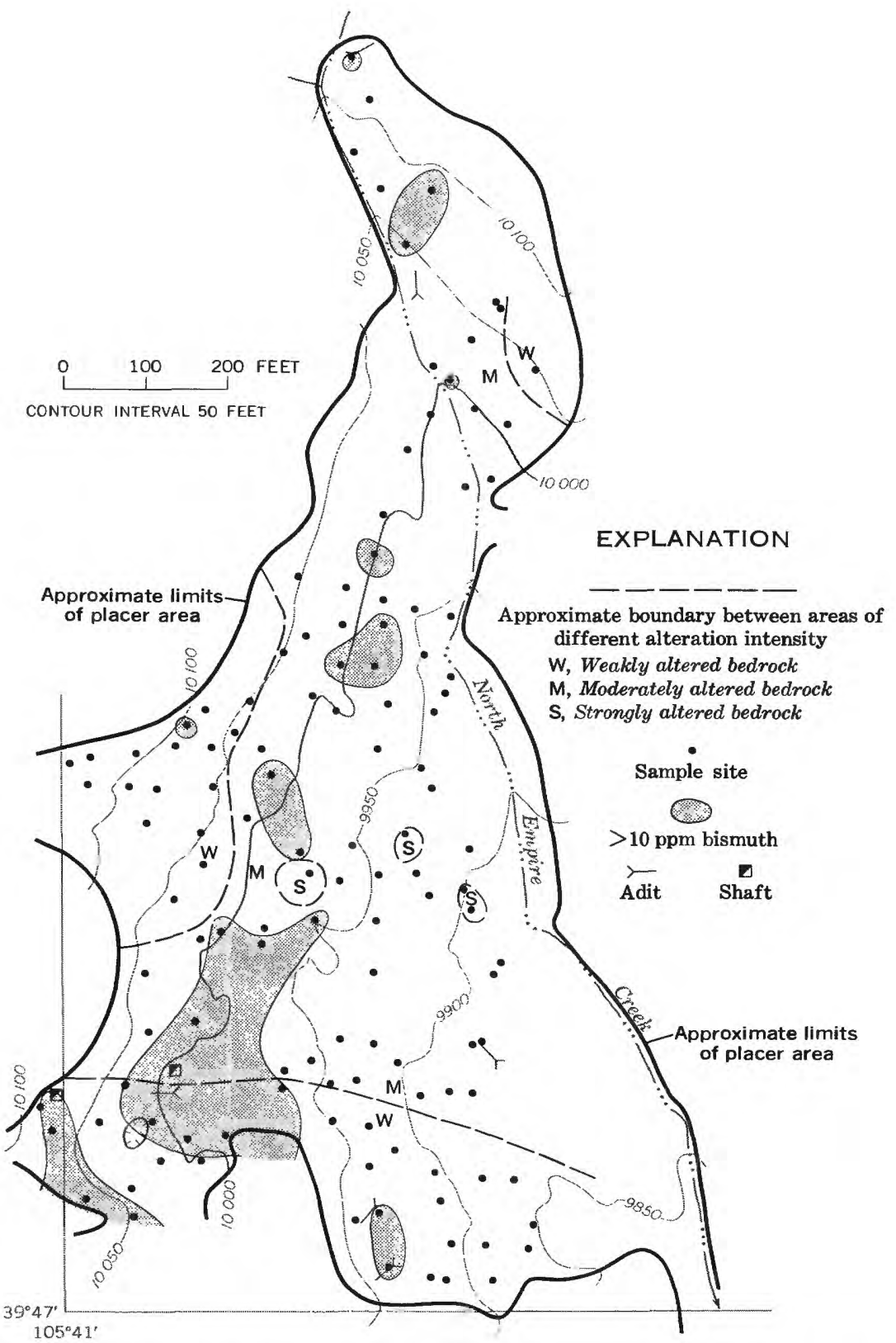

FIGURE 14.-Distribution of bismuth anomalies and alteration intensities in bedrock, upper placer. 


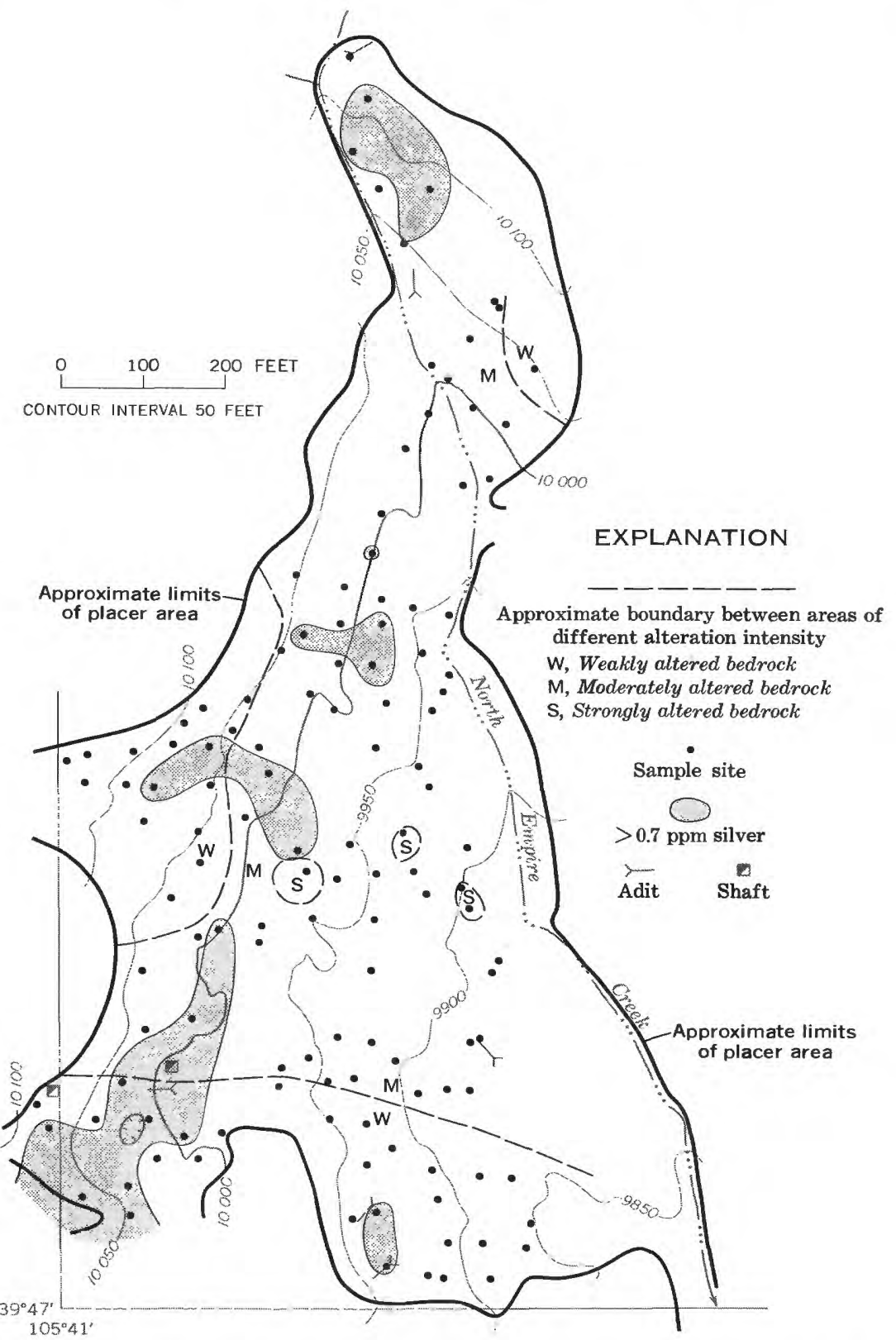

FIGURE 15.-Distribution of silver anomalies and alteration intensities in bedrock, upper placer. 


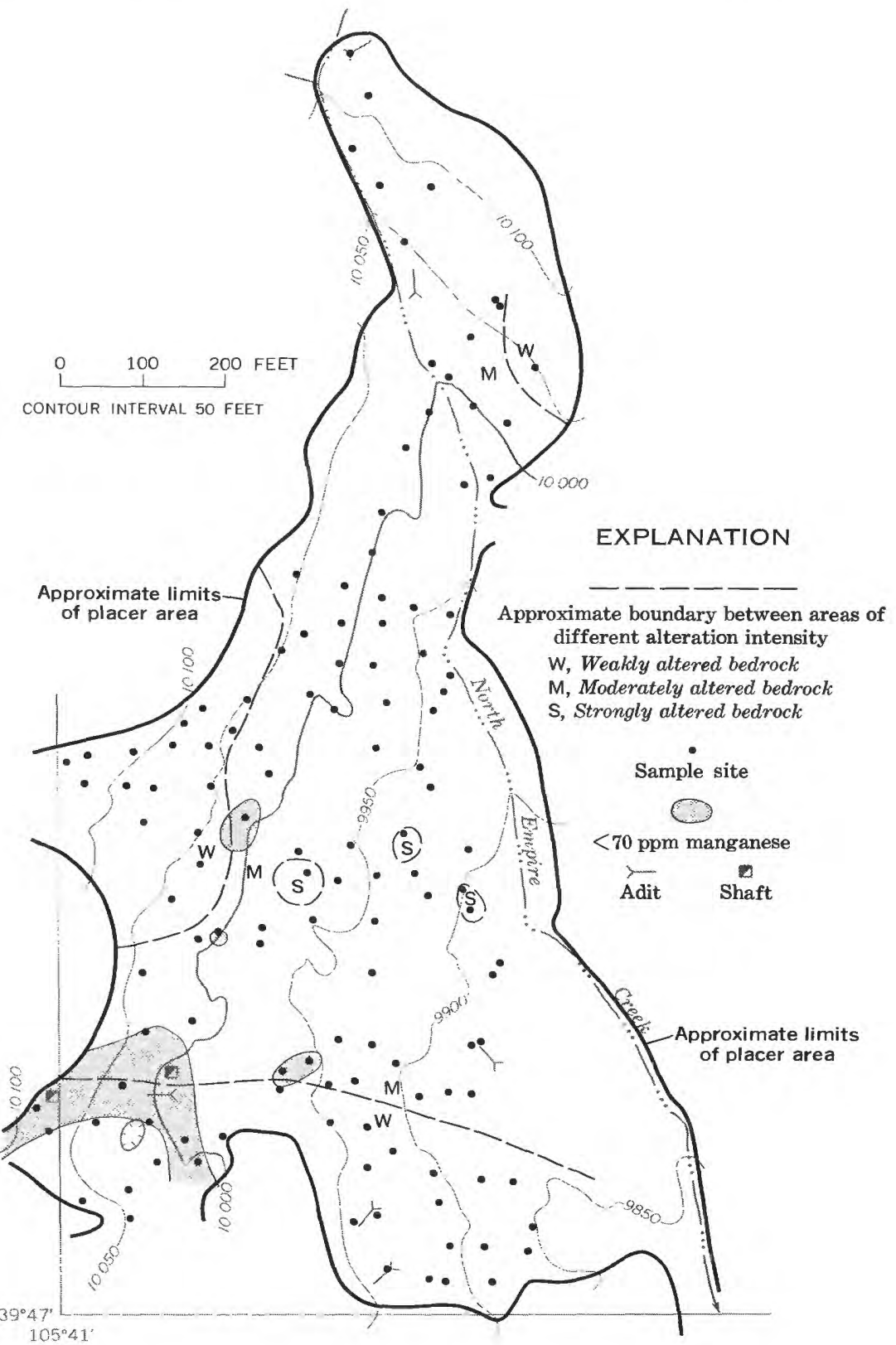

Figure 16.-Distribution of manganese anomalies and alteration intensities in bedrock, upper placer. 
